\title{
MECHANICAL RESISTANCE OF MOSO BAMBOO (Phyllostachys pubescens) PART 2: AXIAL TENSILE STRENGTH, HARDNESS AND WEAR RESISTANCE
}

\author{
Rodrigo Strzelecki Berndsen ${ }^{1}$, Ricardo Jorge Klitzke ${ }^{2}$, Djeison Cesar Batista ${ }^{3}$, Eduardo Mauro do \\ Nascimento ${ }^{4}$, Fabiano Ostapiv ${ }^{5}$ \\ ${ }^{1}$ Mechanical Technologist, M.Sc., UP, Curitiba, PR, Brazil - rodrigoberndsen@ yahoo.com.br \\ ${ }^{2}$ Forest Engineer, Dr., UFPR, Curitiba, PR, Brazil - rklitzke@ufpr.br \\ ${ }^{3}$ Forest Engineer, Dr., UFES, Jerônimo Monteiro, ES, Brazil - djeison.batista@ufes.br \\ ${ }^{4}$ Mechanical Engineer, Dr., UTFPR, Curitiba, PR, Brazil - nascimento@utfpr.edu.br \\ ${ }^{5}$ Mechanical Engineer, Dr. UTFPR, Pato Branco, PR, Brazil - ostapiv@utfpr.edu.br \\ Received for publication: 06/09/2013 - Accepted for publication: 06/03/2014
}

\begin{abstract}
Bamboo is a natural resource with a wide range of applications, especially moso bamboo (Phyllostachys pubescens Mazel ex H. de Lehaie), which is one of the most used species in the world. The main objective of this work was to determine the axial tensile strength, hardness and wear resistance of moso bamboo culms planted in Paraná, Brazil. Axial tensile strength was tested by the modification of a standard designed for wood; hardness was measured by the Brinell Test method and wear resistance was assessed by the taber abraser method. Analysis of variance with a factorial arrangement was applied to verify the effect of the treatments, resulting from the combination of three ages (one, three and five years old) and three culm positions (base, middle and top), and to check a possible interaction between these factors. No significant interaction was verified between age and position for axial tensile strength and hardness, and these properties increased as the age increased and culm position rose. Moso bamboo has potential for the flooring industry because of its low mass loss in the test of wear resistance and the satisfactory hardness when compared to other bamboo species and to traditional Brazilian timber species.

Keywords: Mechanical properties; age; culm position.
\end{abstract}

\section{Resumo}

Resistência mecânica do bambu mossô (Phyllostachys pubescens) parte 2: tração paralela às fibras, dureza e desgaste abrasivo. O bambu é um recurso natural que tem amplo espectro de utilização, destacando-se o bambu mossô (Phyllostachys pubescens Mazel ex H. de Lehaie) como uma das espécies mais utilizadas no mundo. $\mathrm{O}$ objetivo principal do estudo foi determinar as propriedades mecânicas de resistência à tração paralela às fibras, dureza Brinell e resistência ao desgaste abrasivo de colmos do bambu mossô. A resistência à tração paralela foi determinada modificando-se uma norma específica para madeira; a dureza foi medida pelo método de Brinell e a resistência ao desgaste abrasivo foi avaliada utilizando-se o método do taber abraser. A análise de variância em arranjo fatorial foi aplicada para verificar o efeito dos tratamentos, em que foram combinadas três idades (um, três e cinco anos) e três posições nos colmos (base, meio e topo), analisando-se a possível interação entre os fatores. Não houve interação significativa entre os fatores idade e posição para a resistência à tração paralela às fibras e a dureza Brinell, observando-se que tais propriedades aumentaram com a idade e a posição longitudinal dos colmos. O bambu mossô possui potencial para a fabricação de pisos maciços, por causa da baixa perda de massa no ensaio de resistência ao desgaste abrasivo e pela dureza satisfatória em comparação com outras espécies de bambu e espécies madeireiras tradicionais.

Palavras-chave: Propriedades mecânicas; idade; posição no colmo.

\section{INTRODUCTION}

In China, the use of bamboo is part of the national culture, with different species used in architecture, civil construction, production of energy, production of panels, clothes, furniture, small objects and even for food production. Among the most used species, Phyllostachys pubescens Mazel ex 
H. de Lehaie deserves a special mention, since it reaches maturity for cellulose production at the age of three years, and when it reaches five years is ready to be used in the solid form. Considering the solid products made of bamboo, glued laminated floors and wood veneers for furniture are examples among the ones with the higher added value (ASIAN BAMBOO, 2013). If Brazil was to follow the Chinese tradition, bamboo could be a viable alternative for the production of floors, keeping in mind the diversity of species, the ease of cultivation and the fast growth rates.

The supply of woodwork industry in Brazil is divided between sources from native forests and planted forests, where these last ones have proven to be a sustainable alternative. The most cultivated species in the country belong to the genera Eucalyptus and Pinus, respectively with $70.8 \%$ and $22 \%$ of the total, with the remaining $7.2 \%$ divided between rubber tree, acacia, paricá, teak, araucaria, poplar and others, according to data from the Associação Brasileira dos Produtores de Florestas Plantadas (ABRAF 2013).

According to information from Associação Nacional dos Produtores de Pisos de Madeira Maciça (ANPM, 2011), the Brazilian flooring industries work mainly with eight native species, and $68 \%$ of the manufactured product is known to be originated by just three, Hymenaea courbaril L., Tabebuia sp. Gomes ex DC. and Dipteryx odorata (Aublet.) Willd. ANPM points out that the use of few species is a problem for the entire production chain, not only for the industry itself, but also for the forest management. According to data from ABRAF (2013), no one of those three species is part of a reforestation program for production. Among the planted species, only teak (Tectona grandis L.f.) has a potential for the production of floors, because of its desirable physical, mechanical and organoleptic properties. Some species of eucalyptus, mainly the densest ones, also have potential, however, they are not among the most cultivated in Brazil.

Hardness is a property related to wear resistance, and both are important for the choice of a species in order to produce floors (TSOUMIS, 1991). Meanwhile, information on hardness and wear resistance of Phyllostachys pubescens wood, and also of other species of bamboo, are rare in literature.

The mechanical properties of a material will determine its behavior, and their determination is fundamental to give the assessed material a proper use. Although bamboo does not present secondary growth, its mechanical strength behaves like wood in terms of density and moisture. In the same way, mechanical strength is different depending on the different structural directions (longitudinal, tangential and radial), making the bamboo an orthotropic material too (AHMAD, 2000).

The main factors taken in consideration in the assessment of bamboo properties are the age and longitudinal position of the culms (MOHMOD et al., 1990; MOHMOD, 1993; LIESE, 1998; CHUN, 2003; LI et al., 2007). The effect of age in the mechanical properties of Phyllostachys pubescens bamboo wood is important to determine the best moment to harvest the culms, because there is a tendency to a gradual increment of the wear resistance along the first five years, with a reduction of this rate in the following years. Axial tensile strength measured gave mean values of 91.1, 176.4, 184.1, 177.0 and 189.1 $\mathrm{MPa}$, respectively for the age groups of 1-2, 3-4, 5-6, 7-8 and 9-10 years (CHUN, 2003).

Since the stem of bamboo is culm type, longitudinal position is the most important aspect to be assessed for what concerns the position of wood, opposite to the traditional wood, where radial variation is the most significant. In researches with bamboo, the common procedure is to divide culms into longitudinal intervals, and the tendency is an increase of the mechanical strength from the base to the top, together with the increase of density. For the axial tensile strength (parallel to grain) of Phyllostachys pubescens, the mean values obtained were respectively 157.9, 194.2 and 208.9 MPa for the heights of one, three and five meters from the ground, using culms between one and ten years old (CHUN, 2003). Meanwhile, Yu et al. (2008) assessed the axial tensile strength parallel to grain of the same species with five years old samples and obtained mean values that were no significantly different, at the heights of 1.3 and 4.0 meters, respectively with 175.6 and $177.8 \mathrm{MPa}$.

The main objective of this study was to determine the mechanical properties of tensile strength parallel to the grain, Brinell hardness and wear resistance of moso bamboo culms (Phyllostachys pubescens). The specific objective was to investigate the variability of those properties with different positions of the culm (base, middle, top) and with different ages (one, three and five years), looking for the most efficient use of the raw material.

\section{MATERIAL AND METHODS}

This work was the continuation of two previous works and represents the last part. In the first work, basic density and total shrinkage were assessed (BERNDSEN et al., 2010) and the second work focused on 
the static bending and compression strength parallel to grain (BERNDSEN et al., 2013), of moso bamboo culms (Phyllostachys pubescens). The same material and treatments were used in all the situations.

\section{Collection of material}

Moso bamboo culms were collected in the Parque Verde colony, in the municipality of Fazenda Rio Grande, state of Paraná, geographically located at $25^{\circ} 40^{\prime} \mathrm{S}$ and $49^{\circ} 19.5^{\prime} \mathrm{W}$. The mean basal diameter of the chosen culms was $12 \mathrm{~cm}$ and the mean height of the individuals was $17 \mathrm{~m}$. Four culms were collected of each age (one, three and five years), totalizing 12 culms. Only the first $500 \mathrm{~cm}$ of the culms were used, divided into base, middle and top, each section with a length of $100 \mathrm{~cm}$, as shown in figure 1 . The machining methodology of the culms to prepare the slats which originated the specimens is described in Berndsen et al. (2010).

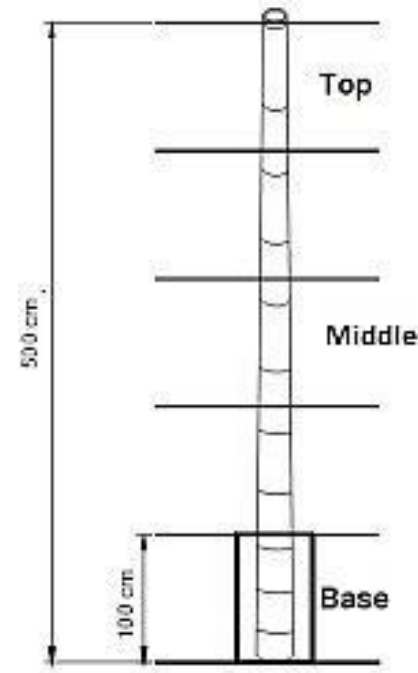

Figure 1. Studied parts of the culms: base, middle and top (Berndsen et al., 2010).

Figura 1. Partes estudadas dos colmos: base, meio e topo (Berndsen et al., 2010).

\section{Determination of the mechanical properties}

At the moment there is not a specific Brazilian standard for the tests of bamboo mechanical properties, therefore the adaptation of standards used for wood was necessary. The main adaptation made in this work regarded the dimensions of the specimens, because the proportion of wooden material in the diameter of bamboo culms is small, thus limiting the preparation of specimens with the dimensions demanded by normal wood standards.

\section{Tensile strength parallel to grain}

Because of the geometric characteristics of the bamboo culms, the specimens to test the tensile strength parallel to grain were prepared with a smaller dimension compared to the ones described by the standard D143-94 of the American Society for Testing and Materials (ASTM, 2000), following the proportions suggested by Ahmad (2000).

Before the test, specimens were conditioned in a climatic chamber with a temperature of $20{ }^{\circ} \mathrm{C}$ and $65 \%$ of relative humidity until constant mass was reached, a process that took about 21 days. The test was performed in a universal testing bench, with a $10 \mathrm{kN}$ load cell and loading speed of $1 \mathrm{~mm} /$ minute. For each treatment, six specimens were used, totalizing 54 specimens for the test, each one with the same nominal dimensions of $20 \times 4 \times 140 \mathrm{~mm}$ (side to side width $\times$ thickness $\times$ length), however, the nominal tested width was $5.5 \mathrm{~mm}$, which resulted in a transversal section equal to $22 \mathrm{~mm}^{2}$. The tensile strength parallel to grain was calculated according to the equation 1.

$$
f_{t}=\frac{\mathrm{P}}{\mathrm{A}}
$$


where: $f_{t}$ : tensile strength parallel to grain (MPa);

P: maximum breaking load $(\mathrm{N})$;

A: transversal section area of the specimen that was broken during the test $\left(\mathrm{mm}^{2}\right)$.

\section{Brinell hardness}

Before this test, specimens were conditioned in a climatic chamber, same as described for the previous test. Nine square specimens were used for each treatment, with sides equal to $20 \mathrm{~mm}$ and $5 \mathrm{~mm}$ thick, totalizing 81 specimens for the test. Hardness test was performed in a Brinell Test Machine where each specimen was continuously loaded on the external surface (closest to the bark) until it reached the maximum load during 15 seconds, and then this load was maintained for 30 seconds.

To measure the diameter of the holes produced during the test, a cylindrical part covered with carbon paper was used, and then its diameter was measured with a tridimensional microscope with 0.005 $\mathrm{mm}$ resolution. The Brinell hardness was measured according to equation 2.

$$
\mathrm{BH}=\frac{2 \cdot \mathrm{P}}{\pi \cdot \mathrm{D} \cdot\left(\mathrm{D}-\sqrt{\mathrm{D}^{2}}-\mathrm{d}^{2}\right)}
$$

where: BH: Brinell hardness (MPa);

$\mathrm{P}$ : load applied in the test $(\mathrm{N})$;

D: diameter of the sphere $(\mathrm{mm})$;

$\mathrm{d}$ : diameter of the impression on the specimen (mm).

\section{Wear resistance}

The D4060-10 standard of the American Society for Testing and Materials (ASTM, 2010) was used for the wear resistance test. To prepare nine specimens the bamboo slats had to be glued together to form a square board with $100 \mathrm{~mm}$ sides and $5 \mathrm{~mm}$ thick, which was then glued on a plywood. First of all the specimens were acclimatized with the test environment and their mass was determined on a digital balance $(0.001 \mathrm{~g})$.

The Taber Abraser equipment (Figure 2) was prepared with a 1,000 $\mathrm{g}$ load with an $\mathrm{H}-18$ abrading wheel (indicated by the manufacturer). This wheel was chosen to create more wear, similar to the one a floor can face, according to the methodology proposed by Koga et al. (2002).

The test was performed adopting 100 cycles per each phase, until reaching 1,000 cycles, always testing the external side of the wood (closest to the bark). When each phase was over, the specimen was detached from the machine, cleaned with a brush (to remove loose particles) and weighted. The mass loss at the end of each cycle was calculated by the equation 3 .

$$
\mathrm{ML}=\frac{\left(\mathrm{M}_{\mathrm{i}}-\mathrm{M}_{\mathrm{f}}\right)}{\mathrm{M}_{\mathrm{i}}} \times 100
$$

where: ML: Mass Loss (\%);

Mi: Initial Mass (g);

Mf: mass at the end of each cycle (g).

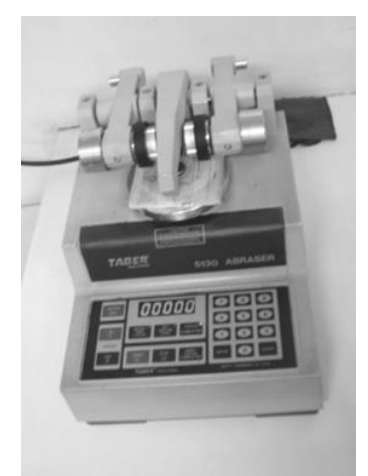

Figure 2. The Taber Abraser equipment used in the wear resistance test.

Figura 2. Equipamento Taber Abraser usado no ensaio de resistência ao desgaste abrasivo. 


\section{Statistical analysis}

In table 1 are shown the treatments resulting from the combination of ages and positions studied.

Table 1. Treatments assessed.

Tabela 1. Tratamentos avaliados.

\begin{tabular}{lcc}
\hline Treatment & Age (years) & Position \\
\hline 1 & 1 & Base \\
2 & & Middle \\
3 & 3 & Top \\
4 & 3 & Base \\
5 & & Middle \\
6 & & Top \\
7 & 5 & Base \\
8 & & Middle \\
9 & & Top \\
\hline
\end{tabular}

From the combination of three ages and three positions in the culms resulted the nine treatments that were submitted to the tensile strength parallel to grain test and to the Brinell hardness test, which were analyzed with a completely randomized design. The analysis of variance (ANOVA) in factorial design (95\% of probability) was applied to verify the effect of the treatments, where three ages (one, three and five years) and three positions in the culms (base, middle, top) were combined to result in a $3 \times 3$ matrix, analyzing the possible interaction between factors. When the null hypothesis was rejected, the Tuckey test (95\% of probability) was applied to verify if differences between the means were significant.

The wear resistance test was performed using nine specimens, one per each treatment, thus it was not possible to perform a statistical analysis as it was done for the other tests. The objective of the wear analysis was to provide a characterization of the analyzed material for the studied species.

\section{RESULTS AND DISCUSSION}

\section{Tensile strength parallel to grain}

Specimens initially built for the tensile strength test fractured due to shear stress in the grip section, as shown in figure 3 . Thus, specimens were rebuilt with smaller width and thickness in the gauge section (as described in the methodology), obtaining the tensile rupture where expected.

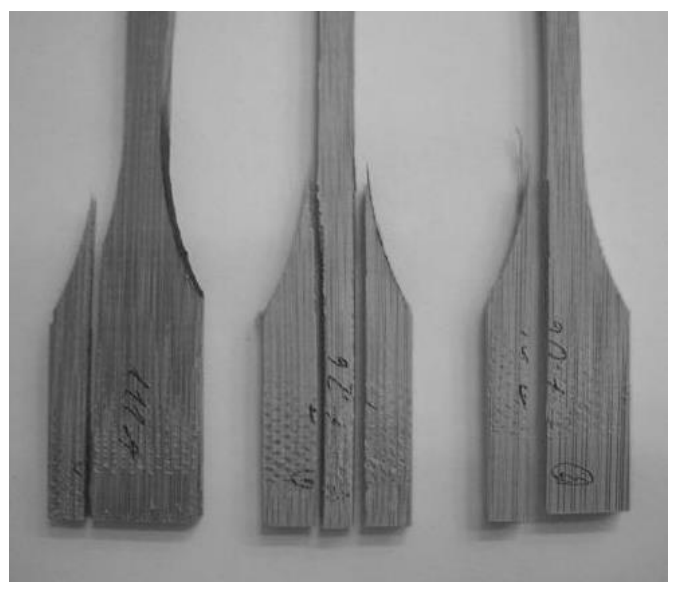

Figure 3. Specimens initially prepared for the tensile strength parallel to grain test.

Figura 3. Corpos de prova inicialmente preparados para o ensaio de resistência à tração paralela às fibras. 
According with the results of ANOVA (95\% of probability), there was no significant interaction between the age and position factors $\left(\mathrm{F}\right.$ calculated $\left.=1,93^{\text {ns }}\right)$ for the tensile strength parallel to grain. Thus, factors were separately analyzed, and the means, broken down by age and position, are shown in table 2 .

Table 2. Analysis of the age and culm position factors in the tensile strength parallel to grain test Tabela 2. Análise dos fatores idade e posição no colmo para o ensaio de resistência à tração paralela às fibras.

\begin{tabular}{lccc}
\hline Age & $\begin{array}{c}\text { Tensile strength parallel } \\
\text { to grain (MPa) }\end{array}$ & Position & $\begin{array}{c}\text { Tensile strength parallel } \\
\text { to grain (MPa) }\end{array}$ \\
\hline 1 & $159 \mathrm{a}$ & Base & $154 \mathrm{a}$ \\
& $(21)$ & & $(29)$ \\
3 & $166 \mathrm{a}$ & Middle & $173 \mathrm{~b}$ \\
& $(24)$ & Top & $175 \mathrm{~b}$ \\
5 & $176 \mathrm{~b}$ & & $(15)$ \\
\hline F calculated & $(16)$ & F calculated & $16.80^{* *}$ \\
Overall Mean & $8.72^{* *}$ & $167(20)$ & \\
\hline
\end{tabular}

Means followed by the same letter in the same column do not differ according with Tukey's test at 95\% of probability. Values between brackets correspond to the coefficient of variation (\%). **Statistically significant at $99 \%$ of probability.

Considering the age factor, the highest tensile strength parallel to grain was observed in five years old samples (176 MPa), and there was no statistically significant difference between one and three years old samples. Results are within the intervals found by Chun (2003), who obtained means between 91.1 and 184.1 MPa, respectively for the ages of 1 and 6 years. The tendency was the same in both works, since tensile strength parallel to grain increased its absolute values as the age of culms increased too.

Considering the position factor, the highest means were obtained by the specimens from the middle and top, with no significant difference, while the lowest mean was obtained by the base culms (154 MPa). Those results were inferior to the ones reported by Chun (2003), who obtained means equal to 158, 194 and $209 \mathrm{MPa}$, respectively for moso bamboo culms at one, three and five meters from the ground, same positions assessed in this work, however considering culms between one and ten years old. Results were also inferior to the ones from Yu et al. (2008), who obtained a mean of $178 \mathrm{MPa}$ from five years old culms, collected at four meters from the ground. Thus, in general, tensile strength parallel to grain of the culms was inferior to what reported in literature (CHUN, 2003; YU et al., 2008), independently from age and position of the culms. Those results may be explained by the differences between cultivation techniques and edaphoclimatic conditions in Brazil and China, locations where the studies being compared were performed.

In terms of technological properties, density is one of the main factors having influence on the mechanical resistance (TSUOMIS, 1991). Considering the position factor, tensile strength parallel to grain had the same behavior in the differentiation of means of the basic density (BERNDSEN et al., 2010), while considering the age factor, behavior of bamboo submitted to parallel tensile stress was equal to the behavior of the basic density only in terms of absolute values. Resuming, tensile strength of moso bamboo increased with basic density, age and height of the culm.

The overall mean value of moso bamboo tensile strength was compared to the mean value of massaranduba (Manilkara spp.), which is one of the most used species in Brazil for the construction of wood structures. According to the reference values for wood structures calculation, indicated by the Associação Brasileira de Normas Técnicas in the NBR 7190 (ABNT, 1997), the tensile strength of massaranduba is $138.5 \mathrm{MPa}$, for an apparent density $(12 \%)$ of $1,143 \mathrm{~kg} / \mathrm{m}^{3}$, that is to say $0.12 \mathrm{MPa} / \mathrm{unit}$ of density. Tensile strength parallel to grain of moso bamboo was equal to $167 \mathrm{MPa}$, for a basic density equal to $670 \mathrm{~kg} / \mathrm{m}^{3}$ (BERNDSEN et al., 2010), that is to say a tensile strength versus density ratio more than twice as great $(0.25 \mathrm{MPa}$ /unit of density) than the one of massaranduba.

It is important to notice that this comparison is not exact, because the considered densities are not the same (basic and apparent), where basic density is smaller, thus making the tensile strength versus density ratio of moso bamboo a little smaller too, in case the apparent density (12\%) was used. Another fact to be considered is the test methodology, which considered specimens free of knots in the culms, besides the use of differentiated standards for the tests. However, those results indicate the potential for 
the use of bamboo culms in the civil construction industry, being a material capable to add mechanical strength to a structure without adding proportional weight.

\section{Brinell hardness}

Same as the tensile strength parallel to grain test, there was no significant interaction between age and position factors $\left(\mathrm{F}\right.$ calculated $=1.18^{\mathrm{ns}}$ ) for the Brinell hardness, as per the results from ANOVA ( $95 \%$ of probability). Thus, factors were analyzed separately, and the means, broke down by age and position are shown in table 3 .

Brinell hardness increased with the age of moso bamboo culms, where the greatest hardness was obtained in the five years old culms, and the lowest was registered in the one year old culms. Considering the position factor, there was the same behavior, however in absolute terms, where the Brinell hardness increased from the base to the top. However, the mean hardness of the culms in the middle was intermediary between the base and top positions, but it was not statistically different from the other two. In general, Brinell hardness of moso bamboo increased with age of culms and from base to top, same behavior observed in the tensile strength parallel to grain.

Considering the age factor, Brinell hardness followed the same behavior of the basic density, where the means of all the treatments were different depending on age, respectively with $0.60,0.67$ and $0.76 \mathrm{~g} / \mathrm{cm}^{3}$ for one, two and five years old culms (BERNDSEN et al., 2010). Same occurred with the position factor, but only in absolute terms, with means equal to $0.63,0.69$ and $0.71 \mathrm{~g} / \mathrm{cm}^{3}$ respectively for base, middle and top.

Table 3. Analysis of the age and position factors in the Brinell hardness Test.

Tabela 3. Análise dos fatores idade e posição para o ensaio de dureza Brinell.

\begin{tabular}{lccc}
\hline Age & Brinell Hardness (MPa) & Position & Brinell Hardness (MPa) \\
\hline 1 & $45 \mathrm{a}(16)$ & Base & $49 \mathrm{a}(20)$ \\
3 & $51 \mathrm{~b}(16)$ & Middle & $52 \mathrm{ab}(21)$ \\
5 & $63 \mathrm{c}(11)$ & Top & $55 \mathrm{~b}(22)$ \\
\hline F calculated & $57,11^{* *}$ & F calculated & $4,71^{*}$ \\
Overall mean & & $52(21)$ & \\
\hline Meral
\end{tabular}

Means followed by the same letter in the same column do not differ according with Tukey's test at $95 \%$ of probability. Values between brackets correspond to the coefficient of variation $(\%)$. *Statistically significant at $95 \%$ of probability. **Statistically significant at $99 \%$ of probability.

There is scarce literature about the results of Brinell hardness of moso bamboo, although the species has great importance for the production of floors, a product where hardness is a very desirable quality. Comparison with other species is also difficult, because in the flooring industry wood hardness is usually determined with the Janka Test.

According to the technical information provided by the company Moso Bamboo Surfaces (2013), obtained from a catalog of a solid wood floor made with Phyllostachys sp., commercially known as Purebamboo, the Brinell hardness of the product is $39 \mathrm{MPa}$. According to the Chinese company Eco (2013), the Brinell hardness of Phyllostachys pubescens bamboo, used for the production of floors, is 46 MPa. Thus, the mean hardness of the material analyzed in this work (52 MPa) was greater than the one presented by the two companies, indicating that the Brazilian material also has adequate qualities for the production of floors.

Brinell hardness of moso bamboo was similar to the one of Hymenaea courbaril (55 MPa), popularly known as jatoba, which is one of the most used species in the world for the production of floors (REAL WOOD, 2013), emphasizing once again the potential of Phyllostachys pubescens planted in Brazil for the production of bamboo floors.

\section{Wear resistance}

Figure 4 shows the graphic evolution of the average mass loss per cycle, demonstrating that it follows a linear pattern.

The overall average mass loss after 1,000 cycles was equal to $0.70 \%$, with a coefficient of variation equal to $19.12 \%$. This value of variation was not considered high because the raw material used 
to prepare the specimens to be tested was very heterogeneous, originated by three different ages (one, three and five years old culms) and three positions in the culm (base middle and top). The average mass loss of Phyllostachys pubescens was lower than Dendrocalamus giganteus Wall. ex Munro bamboo examined by Koga et al. (2002), which resulted in $1.07 \%$ under the same test conditions. This demonstrates that moso bamboo has potential for the production of veneer floors too.

Since solid wood is the most important raw material for the production of solid wood floors in Brazil, it was also worth a comparison with some of the traditional species, like the Brazilian ipê (Tabebuia impetiginosa (Mart. Ex DC.) Standl.), peroba-rosa (Aspidosperma polyneuron Müll. Arg.) and massaranduba (Manilkara elata (Allemão ex Miq.) Monach.). Koga et al. (2002) obtained for ipe and peroba-rosa respectively, average mass losses equal to $1.21 \%$ and $0.83 \%$; in other words the wear resistance of moso bamboo was greater than the one of those traditional timber wood species. However, massaranduba was more resistant than moso bamboo, with average mass loss of 0.62\% (KOGA et al., 2002).

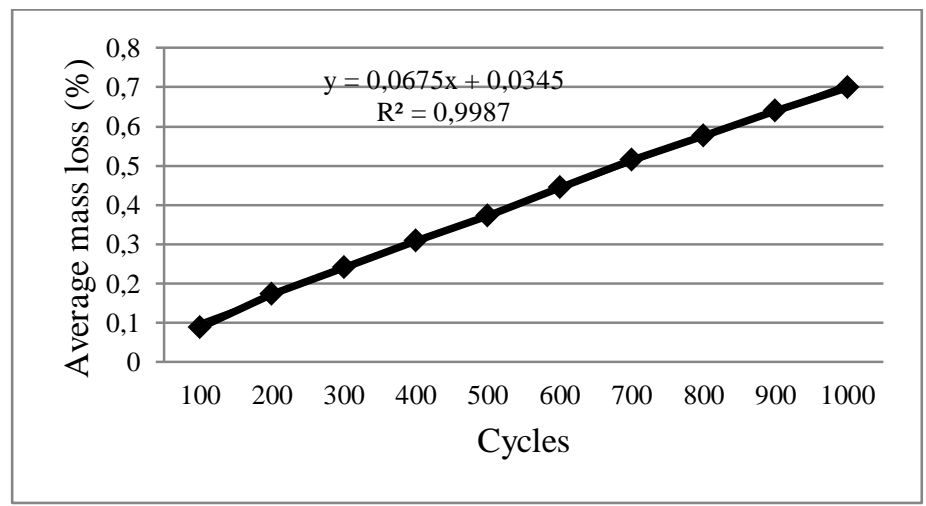

Figure 4. Average mass loss per cycle in the wear resistance test.

Figura 4. Perda de massa média por ciclo no ensaio de resistência ao desgaste abrasivo.

According to information from the database called "Informações sobre madeiras" of the Instituto de Pesquisas Tecnológicas de São Paulo (IPT, 2013), the species ipe, peroba-rosa and massaranduba have respectively a basic density equal to 840,660 and $833 \mathrm{~kg} / \mathrm{m}^{3}$. The basic density of moso bamboo resulted $670 \mathrm{~kg} / \mathrm{m}^{3}$ (BERNDSEN et al., 2010), which means that greater densities not always result in greater wear resistance. This statement is supported comparing the mass loss of moso bamboo (which has lower density) with the mass loss of ipe. In all the other cases, the relation density-wear was confirmed (TSOUMIS, 1991).

\section{CONCLUSIONS}

- The tensile strength parallel to grain and Brinell hardness of moso bamboo increased with age and with the longitudinal position of the culms, where the age of one year/base position (one meter) presented the lowest strength, and the age of five years/top position (five meters) presented the greatest mechanical strength.

- There was no significant interaction between age and position factors for the tensile strength parallel to grain and the Brinell hardness.

- Moso bamboo has potential for the production of solid floors, due to the low mass loss in the wear resistance test and for the satisfactory hardness when compared to other bamboo species and traditional woods.

\section{AKNOWLEDGEMENTS}

The first author is pleased to express his acknowledgements to Coordenação de Aperfeiçoamento de Pessoal de Nível Superior (CAPES), for according the Master level scholarship during the development of the research. 


\section{REFERENCES}

AHMAD, M. Analysis of calcutta bamboo for structural composite materials. 2000. 210 f. Tese (Doutorado em Ciência da Madeira e Produtos Florestais) - Faculty of Virginia Polytechnics Institute and State University, Virginia, 2000.

AMERICAN SOCIETY FOR TESTING AND MATERIALS. ASTM D 143-94: abrasion resistance of organic standard test methods for small clear specimens of timber. Philadelphia, 2000.

AMERICAN SOCIETY FOR TESTING AND MATERIALS. ASTM D 4060: abrasion resistance of organic coatings by the taber abraser. Philadelphia, 2010.

ASIAN BAMBOO. Bamboo culture. Disponível em: <http://www.asian-bamboo.com/bambooculture/the-history-of-bamboo/>. Acesso em: 08/07/ 2013.

ASSOCIAÇÃO BRASILEIRA DE NORMAS TÉCNICAS (ABNT). NBR 7190: projeto de estruturas de madeira. Rio de Janeiro, 1997.

ASSOCIAÇÃO BRASILEIRA DOS PRODUTORES DE FLORESTAS PLANTADAS (ABRAF). Anuário Estatístico da ABRAF 2013 ano base 2012. Brasília: ABRAF, 2013. 148 p.

ASSOCIAÇÃO NACIONAL DOS PRODUTORES DE PISOS DE MADEIRA. (ANPM) Análise tecnológica e econômica do setor brasileiro de pisos de madeira. $1^{\text {a }}$ edição. Piracicaba: ANPM, 2011. 69 p.

BERNDSEN, R. S.; KLITZKE, R. J.; BATISTA, D. C.; NASCIMENTO, E. M.; OSTAPIV, F. Propriedades físicas do bambu mossô (Phyllostachys pubescens) em diferentes idades e posições do colmo. Floresta, Curitiba, v. 40, n. 1, p. 183 - 192, 2010.

BERNDSEN, R. S.; KLITZKE, R. J.; BATISTA, D. C.; NASCIMENTO, E. M.; OSTAPIV, F. Resistência à flexão estática e à compressão paralela do bambu mossô (Phyllostachys pubescens). Floresta, Curitiba, v. 43, n. 3, p. 485 - 494, 2013.

CHUN, Z. F; The production and utilization of bamboo forest in China. Hangzhou: China National Research Center of Bamboo-CBRC, 2003.

ECO. Product FAQ. Disponível em: < http://www.eco-bambooflooring.com/Content/Faq.html >. Acesso em: 02/09/ 2013.

INSTITUTO DE PESQUISAS TECNOLÓGICAS DE SÃO PAULO (IPT). Informações sobre madeiras. Disponível em: <http://www.ipt.br/consultas_online/informacoes_sobre_madeira/busca >. Acesso em: 10/07/ 2013.

KOGA, R. C.; BITTENCOURT, R. M.; GONÇALVES, M. T. T. Resistência à abrasão do bambu gigante e espécies de madeiras para utilização como elemento de piso. In: ENCONTRO BRASILEIRO EM MADEIRAS E EM ESTRUTURAS DE MADEIRA, 8. 2002, Uberlândia. Anais do... Uberlândia: UFU, 2002. 1 CD-ROM.

LI, X. B.; SHUPE, T. F.; PETER, G. F.; HSE, C. Y.; EBERHARDT, T. L. Chemical changes with maturation of the bamboo species Phyllostachys pubescens. Journal Tropical Forest Science, Kepong, v. 19 , n. 1 , p. 6 - 12, 2007.

LIESE, W. The Anatomy of bamboo culms. INBAR - International Network for bamboo and rattan. China: Technical Report, 1998. 204 p.

MOHMOD, A. L.; ARIFFIN, W. T. W.; AHMAD, F. Anatomical features and mechanical properties of three malaysian bamboos. Journal Tropical Forest Science, Kepong, v. 2, n. 3, p. 227 - 234, 1990.

MOHMOD, A. L. Effects of age and height of three bamboo species on their machining properties. Journal Tropical Forest Science, Kepong, v. 5, n. 4, p. 528 - 535, 1993.

MOSO BAMBOO SURFACES. Purebamboo - Solid strip. Disponível em: <http://www.mosobamboo surfaces.co.uk/userfiles/File/pdf/20120801222255_PUREBAMBOO-SOLID_STRIP_DATASHEET.pdf >. Acesso em: 02/09/ 2013. 
REAL WOOD. Durability. Disponível em: 〈http://www.realwood.eu/en/advantages/durability. php >. Acesso em: 02/09/ 2013.

TSOUMIS, G. Science and technology of wood: structure, properties, utilization. New York: Chapman \& Hall, 1991. 494 p.

YU, H. Q.; JIANG, Z. H.; SHUPE, T. F. Selected physical and mechanical properties of moso bamboo (Phyllostachys pubescens). Journal Tropical Forest Science, Kepong, v. 20, n. 4, p. 258 - 268, 2008. 